\title{
Exploration of the Innovative Teaching Modes of Application-oriented Universities in Theory and Practice
}

\author{
Chengxian Zhou \\ Departme School of Electric Engineering \& Automation, \\ Xiamen University of Technology, Xiamen 361024, China \\ zchx258@163.com
}

\begin{abstract}
With a view to the problems existing in the combination of the application-oriented undergraduate teaching modes in theory and practice, the paper takes the innovative teaching mode of discipline competition special topic as the research object, tries to explore the effective ways and methods of application-oriented undergraduate to train professional talents, and studies the coordinated and balanced development mode in practice and theory. It discusses how the teaching mode of discipline competition runs through practice and theory, promotes further students to apply their professional theoretical knowledge through discipline competition, and puts forward the practical teaching system and method by which teachers can improve teaching efficiency by means of competition, stimulate students to understand practice, and effectively train students in problem analysis and solving, knowledge application and innovation.
\end{abstract}

Keywords-Innovative teaching mode; Theory and practice;Means of competition.

\section{INTRODUCTION}

In order to keep up with the goal of building an innovative country, colleges and universities must promote quality education in an all-round way, which means that teachers must be with stronger innovation capability as well as stronger theoretical accomplishment and solid basic skills. Transitional colleges and universities should focus on training students in application-oriented skills and strengthening theoretical construction[1]. After all, only the shoulder-to-shoulder and coordinated development in practice and theory can promote students to enhance the comprehensive strength. In order to develop application-oriented talents, colleges and universities should enable students to be with solid theoretical basis, but also propel students to participate in practice, arouse their interest in independent thinking and active learning, and improve their practical ability and manipulative ability[2,3].

In the actual operation, there are still many problems in the mode and process of personnel training of application-oriented universities, especially how to further train undergraduates in problem analysis and solving and innovation[4,5]. Teachers have always studied how to closely combine practice with theory and distribute practice and theory[6]. Practice should be guided by theory and theory should serve practice. It is urgent to find out a mode to closely combine practice and theory, embody the theoretical knowledge that students master in practice, explore the bridge between practice and theory, and put forward effective measures[7]

With a view to the problems existing in the combination of the application-oriented undergraduate teaching modes in theory and practice, the paper takes the innovative teaching mode of discipline competition special topic as the research object, tries to explore the effective ways and methods of application-oriented undergraduate to train professional talents, studies the coordinated and balanced development mode in practice and theory, and builds the practical teaching system and method by which teachers can effectively train students in problem analysis and solving, knowledge application and innovation.

\section{SIGNIFICANCE OF DISCIPLINE COMPETITION}

It discusses the way to make discipline competition run through practice and theory, and further drive students to apply their professional knowledge and inspires students to understand practice through discipline competition. By means of discipline competition, students can form the sense of competition, carry forward the team work spirit, broaden the scope of knowledge, and develop innovative thinking and practical and manipulative ability. It takes discipline competition as the means, replaces practice with competition, highlights the ability of electrical majors in collaborative software and hardware design, improves the ability of students in systematic engineering design, team cooperation and innovative design, and develops the confidence of students in employment and entrepreneurship. 


\section{CONCRETE IMPLEMENTATION METHODS}

\section{A. Promote students to complete courses through competition and stimulate students to be a useful person with their achievements}

Dependent on the open scientific and innovative center of electronic information, it organizes students to participate in competition in order to orderly build the extracurricular scientific and technological innovation activity system for college students. Various scientific and technological competitions with fierce competitiveness and challenge are a very good platform to test, exercise, improve and display the scientific and technological innovation ability of college students. It applies the innovative practice teaching projects such as "Challenge Cup", electronic design competition, MCUcompetition, national smart vehicle competition and innovative projects for college student to innovative practice base platform, runs them through the whole teaching practice of electrical majors, and teaches and guides electrical majors in practical courses by different levels based on the students' interests, professional foundation, special skills and others. It replaces practice with competition to improve the ability of students in practice, team cooperation and innovation.

The second and following paragraph under the first and second level titles (the Introduction part is excluded) need to indented for one character. Please do not forget.

\section{B. Explore the open interdisciplinary teaching mode}

It organizes the students from different schools and majors to participate in competition, develops the teams in which team members can communicate and cooperate with each other and learn from each other, builds the electrical practice base open for all students and the resource sharing platform. It also creates a strong academic atmosphere, carries out independent learning and mutually supportive research, and enables students to directly experience the process producing creative thinking and quickly grasp the methods of innovative thinking in the practice - research - re practice -re research process.

Require students to participate in competition in order to stimulate them to take initiative in their studies(1) Students should be in the laboratory not less than 40 hours a week. The laboratory is open all day and provides the basic components; (2) Students are required to submit the weekly journal each week and write the progress, existing problems and the next plan of the competition project; (3) Competition mechanism and reward and punishment system are introduced to the usual training in order to improve learning efficiency and train interestingness;The tasks assigned to different grades in the stepped developing mode are as follows : Freshmen grasp the basic hardware knowledge of analog electronics and digital circuitry, combine the electrical and electronic department of modern training center to carry out welding competition, radio assembly, and contact electrical practice to train manipulative skills and achieve cognitive practice.Sophomore study circuit diagram design and MCU programming, hold and participate in small car tracking competition, and combine the practice department of the student union to carry out social practice activities such as "home appliance duty maintenance".Junior students form a team to participate in Freescale smart car race for national college students and international competitions such as electronic competitionSenior students participate in some scientific research projects and guide junior students to participate in practical activities.

Let us take electrical discipline competition as an example. Colleges and universities establish multidisciplinary crossed competition projects, including the five aspects of hardware circuit design, software programming technology, automatic control technology, mechanical design technology, and comprehensive system reliability design. It is the most effective path from theory to practice for students to participate in discipline competition as the teaching activity. During the period, students need to constantly overcome setbacks, adjust their mentality, and make a positive progress. It is more helpful to promote students to develop rigorous and realistic style, the spirit of building a harmonious team, and exercise gritty will and quality. After grasping the basic learning ideas, students must think carefully, take the initiative to find out the ways to solve problems, and give play to creative thinking to the greater extent. It is an important change that students move from classroom to social practice. Strengthened smart car competition courses for college students are listed as follows:

\section{Strengthened theoretical courses}

Circuit Theory, Analog Electronic Technology, Digital Electronic Technology, C Language Program Design, Power Electronic Technology, MCU Principle and Application, Automatic Control Principle, Detection and Sensor Technology, Pattern Recognition

\section{Strengthened theoretical coursesStrengthened practical teaching}

Electrical Drawing Skill Training, Electronic Process Practice, Electrical Practice, Analog Electronic Technology Experiment, Digital Electronic Technology Experiment, MCU Principle and Application Experiment

\section{E. Strengthened theoretical coursesStrengthened comprehensive design courses}

Analog Electronic Technology Course Design, Digital Electronic Technology Course Design, C Language Program Course Design, MCU Principle and Application Comprehensive Training, Creative Training of Electronic System Design, Graduation Design 
Colleges and universities can enable students to combine basic electrical knowledge in theory and practice through smart car competition, train students in innovative practice through fierce discipline competition with high strength, develop a batch of innovative talents with solid basic professional knowledge, strong manipulative ability and popular with society, and further shape the electrical brand image of science and technology.

\section{SUMMARY}

Colleges and universities train students in innovative practice through continuous discipline competition with high strength, so that they can develop a batch of innovative talents with solid basic professional knowledge, strong manipulative ability and popular with society, and further shape the electrical brand image of science and technology, further shape the electrical brand image of science and technology. They focus on the design and production of the comprehensive, applied and innovative experiments. They also encourage students to make the innovative research and guide students to publish scientific papers on the research projects. They support students to plan and choose experimental topics and organize experiments by themselves based on electrical practice to exercise, develop the innovative ability of students to the greatest extent, and enable students to really grasp the knowledge of electronic theory, electronic design, electronic manufacture and electronic product design from theory to practice.

\section{ACKNOWLEDGEMENT}

This research was financially supported by the School level teaching reform projec.(Project No. JGY201612)

\section{REFERENCES}

[1] G. Paim, C. P., \& Goldmeier, S. (2017). Development of an educational game to set up surgical instruments on the mayo stand or back table: applied research in production technology. Jmir Serious Games, 5(1), e1.

[2] Ismail M, Parsaei H, Kakosimos K. Incorporating Human Factors in Course Design: Utility of Wearable Technologies[M]// Advances in Human Factors, Business Management, Training and Education. Springer International Publishing, 2017.

[3] Pattison M, Mcquaid H, Wilcox A. Incorporating human factors in product design and development[J]. Medical Device Technology, 2007,18 (7):28, 30, 32.

[4] Elsedfy A, Chamberlain R S. Surgeons and their tools: a history of surgical instruments and their innovators--part I: place the scissors on the Mayo stand.[J]. American Surgeon, 2014, 80(11):1089-92.

[5] Sesto M E, Tevaarwerk A J, Wiegmann D A. Human Factors Engineering: Targeting Systems for Change[J]. Health Services for Cancer Survivors, 2011:329-352.

[6] Iton A, Shrimali B P. Power, Politics, and Health: A New Public Health Practice Targeting the Root Causes of Health Equity[J]. Maternal and Child Health Journal, 2016, 20(8):1-6. 